\title{
DAMPAK TERJADINYA EL NINO/LA NINA TERHADAP INTENSITAS, MASA HIDUP DAN FREKUENSI SIKLON
}

\author{
Dendi Rona Purnama*, Kiagus Ardi Zulistyawan \\ Bayu Christian, Desak Putu Okta Veanti \\ Sekolah Tinggi Meteorologi Klimatologi dan Geofisika,Tanggerang Selatan 15221 \\ *Email: deronpurna@gmail.com
}

\begin{abstract}
ABSTRAK
Fenomena badai siklon adalah salah satu bencana hidrometeorologi yang paling merusak di Bumi. Siklon bisa terjadi di kawasan yang dipengaruhi aktivitas El Nino (La Nina). Siklon tropis maupun El Nino dapat menyebabkan kondisi cuaca atau iklim ekstrim di daerah tropis. Pada kajian ini, dilakukan kajian mengenai dampak fenomena El Nino (La Nina) terhadap besar kecilnya badai siklon (intensitas siklon) di sekitar wilayah Indonesia. Besar kecilnya badai siklon tersebut diklasifikasikan dengan menggunakan Skala SaffirSimpson. Selain intensitas, dikaji pula hubungan El Nino (La Nina) dengan masa hidup dan frekuensi kemunculan fenomena siklon di sekitar wilayah Indonesia. Penelitian ini akan membandingkan data siklon pada tahun ketika terjadi peristiwa El Nino (La Nina) dengan data siklon pada tahun ketika tidak terjadi peristiwa El Nino (La Nina). Dalam kajian ini, digunakan data siklon selama 10 tahun (2007-2017) dari situs JAXA (Japan Aerospace Exploration Agency). Selain itu, digunakan juga data indeks El Nino dalam Nino 3.4 sebagai data aktivitas ENSO. Metode yang digunakan dalam penelitian ini menggunakan metode statistik. Dari hasil analisis tersebut, secara umum diperoleh bahwa El Nino (La Nina) memiliki pengaruh positif yang signifikan terhadap intensitas dan masa hidup siklon di sekitar wilayah Indonesia. Secara khusus, El Nino (La Nina) memiliki pengaruh positif yang signifikan terhadap intensitas dan masa hidup siklon di wilayah utara ekuator. Sementara itu, di selatan ekuator tidak menunjukan korelasi yang signifikan. Pengaruh El Nino (La Nina) terhadap frekuensi siklon belum dapat terlihat dengan jelas pada penelitian ini sehingga diperlukan penelitian lebih lanjut mengenai hal ini.
\end{abstract}

Kata kunci: siklon, el nino (la nina), intensitas siklon, masa hidup siklon, frekuensi siklon

\begin{abstract}
Cyclone is one of the most destructive hidrometeorological disaster on the Earth. Cyclone can happen in the area that is influenced by El Nino (La Nina) activity. Both cyclone and El Nino (La Nina) can cause extreme weather condition or extreme climate condition in the tropical area. This research is aimed to find the impact of El Nino (La Nina) phenomenon to intensity of the cyclone around Indonesia. The intensity of cyclone is classified by the Saffir-Simpson Hurricane Scale. Besides, relationship of El Nino (La Nina) with lifetime and frequency of cyclone around Indonesia is also studied. This research will compare between the cyclone data on the year with El Nino (La Nina) and the cyclone data on the normal year. This research is using the cyclone data in 10 years between 2007 until 2017 from the JAXA (Japan Aerospace Exploration Agency) website. Besides, the El Nino index on Nino 3.4 as the data of ENSO activity is also used. The method that is used by the research is the statistical method. From the analysis, generally found that El Nino (La Nina) has significant positive impact to the intensity and the lifetime of cyclones around Indonesia. Specifically, El Nino (La Nina) has significant positive impact to the intensity and the lifetime of cyclones in the northern part of equator. Meanwhile, it doesn't show the significant correlation in the southern part of the equator. The impact of El Nino (La Nina) to the cyclone frequency can't be conducted on this research so that it needs further research.
\end{abstract}

Keywords: cyclone, el nino (la nina), cyclone's intensity, cyclone's lifetime, cyclone's frequency 


\section{PENDAHULUAN}

Fenomena badai siklon adalah salah satu bencana hidrometeorologi yang paling merusak di Bumi. Menurut sejarah, 90\% siklon tropis mematikan. Karena ukurannya yang sangat besar serta angin kencang dan gumpalan awan yang dimilikinya, siklon menimbulkan dampak yang sangat besar pada tempat-tempat yang dilaluinya. Dampak ini bisa berpengaruh terhadap ekologi dan struktur geomorfologi, terutama di lautan (Done, 1992).

Misalnya, Topan Nepartak yang menyapu Taiwan Timur pada Jumat, 8 Juli 2016 yang menyebabkan hujan deras dan angin kencang. Topan ini juga menyebabkan satu orang tewas dan 66 orang terluka, sehingga pemerintah setempat mengevakuasi lebih dari 15.400 orang sebelum terkena dampak yang lebih parah. Dampak Topan Nepartak juga memengaruhi transportasi : lebih dari 300 penerbangan internasional dan 254 penerbangan domestik dibatalkan, layanan kereta api cepat terpaksa dihentikan dan 187.830 rumah terputus dari pasokan listrik (Republika, 2008). Selain Topan Nepartak, masih banyak lagi fenomena badai siklon yang dapat mempengaruhi lingkungan sekitarnya. Siklon tropis maupun El Nino dapat menyebabkan kondisi cuaca atau iklim ekstrim di daerah tropis (Haryani dkk., 2012). Oleh karena itu, siklon dan El Nino (La Nina) merupakan salah satu fenomena alam yang penting dan diperlukan pengkajian mengenai hal tersebut.

Indonesia yang terletak di daerah ekuator bukan merupakan daerah lintasan badai siklon. Namun demikian keberadaan badai siklon di sekitar Indonesia, terutama yang terbentuk di sekitar Pasifik Barat Laut, Samudra Hindia Tenggara dan sekitar Australia akan mempengaruhi pembentukan pola cuaca di Indonesia (Haryani dkk., 2012).

Siklon tropis ialah pusaran atmosferik kuat yang terbentuk di atas lautan tropis yang hangat dan merupakan tingkatan dewasa dalam gangguan tropis (Kepert, 2010; Saha, 2010). Selain itu, siklon tropis merupakan badai sirkuler yang menimbulkan angin perusak sampai daerah sekitar 250 mil dari pusatnya dan memiliki kecepatan angin yang paling kencang terdapat pada cincin yang bergaris tengah 20 mil sampai 30 mil dari pusat siklon (Bayong
2004). Kecepatan minimum untuk dikategorikan sebagai siklon ialah $33 \mathrm{~m} / \mathrm{s}$ atau setara dengan 64 knot (Horstmeyer, 2011). Siklon tropis dapat terbentuk dengan persyaratan berikut ini:

1. Suhu permukaan laut sekurangkurangnya 26.5 C hingga ke kedalaman 60 meter.

2. Kondisi atmosfer yang tidak stabil yang memungkinkan terbentuknya awan Cumulonimbus. Awan-awan ini, yang merupakan awan-awan guntur, dan merupakan penanda wilayah konvektif kuat, adalah penting dalam perkembangan siklon tropis.

3. Atmosfer yang relatif lembab di ketinggian sekitar $5 \mathrm{~km}$. Ketinggian ini merupakan atmosfer paras menengah, yang apabila dalam keadaan kering tidak dapat mendukung bagi perkembangan aktivitas badai guntur di dalam siklon.

4. Berada pada jarak setidaknya sekitar $500 \mathrm{~km}$ dari ekuator. Meskipun memungkinkan, siklon jarang terbentuk di dekat ekuator.

5. Gangguan atmosfer di dekat permukaan bumi berupa angin yang berpusar yang disertai dengan pumpunan angin.

6. Perubahan kondisi angin terhadap ketinggian tidak terlalu besar. Perubahan kondisi angin yang besar akan mengacaukan proses perkembangan badai guntur (Terry, 2007).

ENSO (El Niño-Southern Oscillation) adalah bagian alamiah dari sistem iklim global dan hasil dari interaksi dalam skala besar antara lautan dan atmosfer yang terjadi terutama melewati pusat wilayahnya di Pasifik TropisSubtropis sampai wilayah Samudera Hindia. ENSO juga merupakan fenomena yang tidak teratur dan cenderung terjadi lagi pada rentang waktu 2-7 tahun dan dimanifestasikan dengan adanya pergantian antara 2 fase yang sering disebut El Nino dan La Nina (Allan, 2000).

Selama peristiwa El Nino, pemanasan daerah Samudera Pasifik Tropis dan Samudera Hindia menyebabkan perpindahan produksi curah hujan utama dari benua ke wilayah samudra yang telah disebutkan sebelumnya. 
Kecenderungan sebaliknya terjadi saat La Nina. El Nino dapat berdampak pada Iklim, ekosistem serta aktifitas manusia (Gilantz, 2001).

Dalam skala waktu antar tahun, ENSO dikenal sebagai faktor utama dalam modulasi keberagaman antar tahun dari aktivitas siklon di Pasifik Barat Laut (Lander, 1994; Chan, 1985; Wu dkk., 1992; Camargo dkk., 2005; Chan, 2000). Pada tahun yang terdapat El Nino, siklon tropis terjadi lebih lama dan lebih besar, dengan 3-5 kategori siklon dan sedikit badai siklon yang tidak membesar setelah melalui fase badai tropis (tropical strom) (Camargo dkk., 2005). Pengkategorian badai tersebut biasanya menggunakan Skala Saffir-Simpson (SaffirSimpson Hurricane Scale, SSHS), yaitu pemeringkatan dari 1 sampai 5 pada siklon berdasarkan pada kecepatan angin (tabel 1) (Horstmeyer, 2011). Variasi antar tahun dalam rata-rata masa hidup tahunan, intensitas, dan frekuensi dari siklon semua berkontribusi terhadap sinyal ENSO dalam akumulasi energi siklon, meskipun efek masa hidup siklon tampak menjadi yang paling penting (Camargo dkk., 2005).

Tabel 1. Skala Saffir-Simpson

\begin{tabular}{|c|c|}
\hline Kategori & Keterangan \\
\hline 1 & $\begin{array}{c}64-82 \mathrm{knot} \\
119-153 \mathrm{~km} / \mathrm{jam}\end{array}$ \\
\hline 2 & $\begin{array}{c}83-95 \mathrm{knot} \\
154-177 \mathrm{~km} / \mathrm{jam}\end{array}$ \\
\hline 3 & $\begin{array}{c}96-112 \mathrm{knot} \\
178-208 \mathrm{~km} / \mathrm{jam}\end{array}$ \\
\hline 3 & $\begin{array}{c}113-136 \mathrm{knot} \\
209-251 \mathrm{~km} / \mathrm{jam}\end{array}$ \\
\hline \multirow{2}{*}{5} & $\geq 137 \mathrm{knot}$ \\
& $\geq 252 \mathrm{~km} / \mathrm{jam}$ \\
\hline
\end{tabular}

Tujuan dari penelitian ini adalah untuk melihat apakah ada hubungan antara El Nino (La Nina) dengan intensitas, masa hidup dan frekuensi dari siklon. Untuk kepentingan analisa, siklon yang diteliti akan dikelompokan menjadi dua daerah, yaitu siklon di sebelah utara ekuator dan siklon di sebelah selatan ekuator.

\section{METODE PENELITIAN}

Data yang digunakan dalam penelitian ini adalah data siklon dengan batasan wilayah $90^{\circ} \mathrm{BT}-150^{\circ} \mathrm{BT}$ dan $30^{\circ} \mathrm{LU}-30^{\circ} \mathrm{LS}$ (gambar 1 ). Data siklon ini diperoleh dari situs Japan Aerospace Exploration Agency (JAXA) dari tahun 2007-2017. Untuk membandingkan data yang digunakan dalam penelitian ini yaitu data indeks El Nino dalam Nino 3.4 (SSTA Index Nino 3.4) dalam bentuk mingguan yang diperoleh dari situs BMKG.

Metode yang digunakan dalam penelitian ini menggunakan metode statistik. Dalam penelitian ini akan menganalisis keterkaitan intensitas, frekuensi, dan masa hidup siklon dengan El Nino (La Nina). Data siklon dan data indeks El Nino yang telah dikumpulkan dibuat menjadi scattering plot. Data siklon dipisah antara yang di utara ekuator dan yang di selatan ekuator untuk melihat adanya perbedaan karakteristik dari siklon di masing-masing tempat. Dari hasil scattering plot tersebut, dianalisis koefisien korelasi dan nilai regresinya (R-Value) serta dicari nilai probabilitasnya (PValue). Nilai Probabilitas maksimal yang digunakan adalah 0,05 dimana nilai ini berarti bahwa tingkat kepercayaan terhadap korelasi tersebut adalah sebesar $95 \%$.

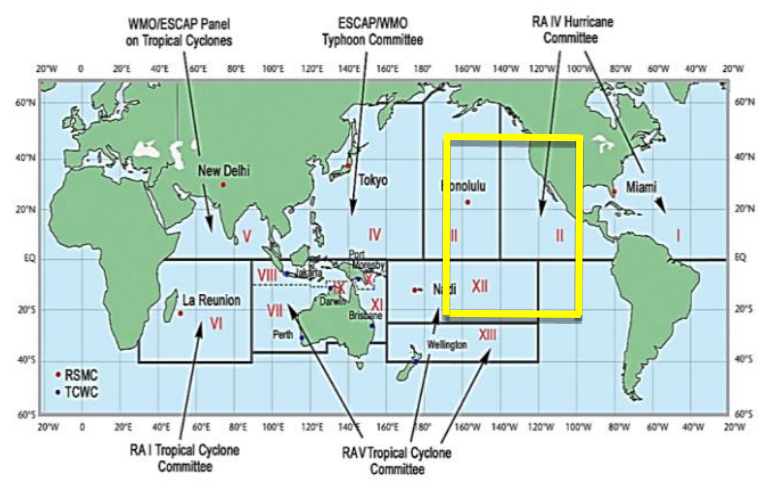

Gambar 1. Peta wilayah pembagian siklon

Menurut Levin \& Rubin (1998:648), regresi digunakan untuk menentGilantukan sifat-sifat dan kekuatan hubungan antara dua variabel serta memprediksi nilai dari suatu variabel yang belum diketahui dengan didasarkan pada observasi masa lalu terhadap variabel tersebut dan variable-variabel lainnya (Levin dkk., 2008).

Dalam penghitungan nilai regresi menggunakan rumus regresi sebagai berikut :

$$
\mathbf{r}=\frac{n \Sigma \mathrm{X}_{\mathrm{i}} \mathrm{Y}_{\mathrm{i}}-\left(\Sigma \mathrm{X}_{\mathrm{i}}\right)\left(\Sigma \mathrm{Y}_{\mathrm{i}}\right)}{\sqrt{\left\{\mathrm{n} \Sigma \mathrm{X}_{1}^{2}-\left(\Sigma \mathrm{X}_{1}\right)^{2}\right\}\left\{\mathrm{n} \Sigma \mathrm{Y}_{1}^{2}-\left(\Sigma \mathrm{Y}_{1}\right)^{2}\right\}}}
$$

Dalam sebuah penelitian yang memiliki banyak variabel, ketika nilai regresinya rendah belum tentu data itu tidak signifikan. Oleh karena itu diperlukan mencari nilai probabilitas (P-Value). Dalam sebuah penelitian menggunakan metode 
statistik diperlukan mencari nilai probabilitas. Nilai-P adalah ukuran dari jumlah pasti dari bukti yang bertentangan (berlawanan) dengan H_0 di mana semakin kecil nilai-P, semakin banyak bukti yang bertentangan (berlawanan) dengan H_0 (Sugiarto, 2009). Jika nilai PValue dari suatu perhitungan data statistik $\leq$ 0,05 , maka perhitungan tersebut bisa disebut signifikan dan sebaliknya.

Untuk analisa frekuensi digunakan histogram dengan 5 pembagian kelas : normal (interval Nino 3.4 dari $(-0,5)-(0,5))$, El Nino kuat (interval Nino $3.4(>2)$ ), El Nino moderat (interval Nino 3.4 dari 1-2), El Nino lemah (interval Nino 3.4 dari 0,5-1), La Nina lemah (interval Nino 3.4 dari $(-0,5)-(-1)$ ), La Nina moderat (interval Nino 3.4 dari (-1)-(-2)), La Nina kuat (interval Nino $3.4(<-2)$ ).

\section{HASIL DAN PEMBAHASAN}

\subsection{Keadaan Siklon di Indonesia}

\subsubsection{Analisis Jumlah Siklon Musiman di sekitar Indonesia}

Analisis mengenai jumlah siklon dalam triwulan diperlukan untuk mengetahui kecenderungan waktu/musim kemunculan siklon di sekitar wilayah Indonesia (daerah penelitian).

Pemisahan antara wilayah utara dan selatan bermaksud agar dapat terlihat karakteristik waktu kemunculan siklon di masing-masing wilayah serta frekuensinya dalam musiman (triwulan). Gambar 2 menjelaskan jumlah siklon yang terjadi pertriwulan tahun 20072017 di sekitar Indonesia.

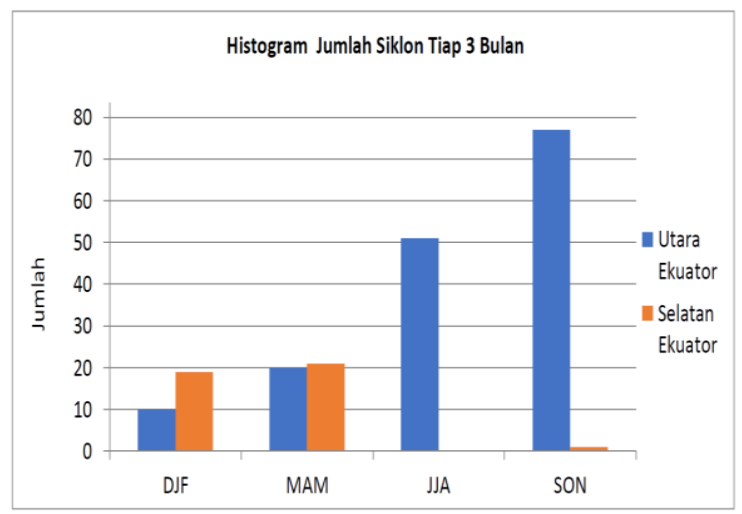

Gambar 2. Histogram jumlah siklon pertriwulan dari 2007-2017 di sekitar Indonesia

Secara umum histogram di atas menunjukkan jumlah siklon yang terjadi pertriwulan dari tahun 2007-2017 dan didominasi oleh siklon yang terjadi di daerah utara ekuator. Pada bulan
DJF (Desember Januari Februari), kemunculan siklon lebih banyak terjadi di selatan ekuator. Hal yang sama terjadi pada bulan MAM (Maret April Mei), meskipun kedua wilayah mengalami peningkatan jumlah kemunculan siklon, tetapi kemunculan siklon lebih banyak terjadi di selatan ekuator.

Pada bulan JJA (Juni Juli Agustus), hanya di daerah utara ekuator saja muncul siklon dari tahun 2007-2017 di sekitar wilayah Indonesia. Pada bulan SON (September Oktober November), frekuensi jumlah siklon di utara ekuator mengalami peningkatan yang cukup drastis dan memiliki frekuensi paling tinggi. Sementara itu, di selatan ekuator hanya terjadi 1 siklon di bulan SON pada kurun waktu 20072017.

Di wilayah utara ekuator hampir setiap musim (triwulan) terjadi siklon, namun yang paling dominan terjadi pada bulan SON dan JJA. Untuk wilayah selatan ekuator hanya dominan pada bulan DJF dan MAM.

\subsubsection{Analisis Rata-rata Masa Hidup Siklon Musiman di sekitar Indonesia}

Analisis rata-rata masa hidup siklon diperlukan untuk mengetahui kecenderungan masa hidup siklon di sekitar Indonesia. Pemisahan antara wilayah utara dan selatan bermaksud agar dapat terlihat rata-rata masa hidup siklon di masingmasing wilayah serta frekuensinya dalam musiman (triwulan). Gambar 3 menjelaskan rata-rata masa hidup siklon yang terjadi pertriwulan dari tahun 2007-2017 di sekitar Indonesia.

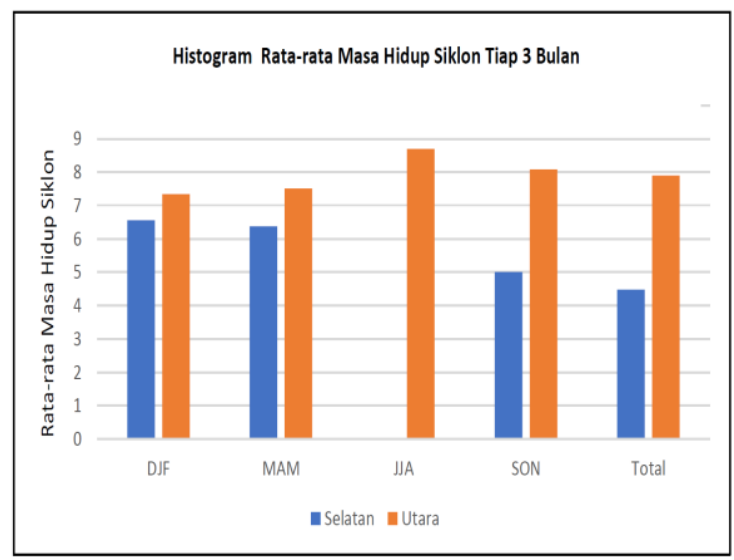

Gambar 3. Histogram rata-rata masa hidup siklon pertriwulan dari tahun 2007-2017 di sekitar Indonesia 
Secara umum histogram di atas menunjukkan rata-rata hidup siklon yang terjadi pertriwulan dari tahun 2007-2017 di sekitar Indonesia. Terlihat bahwa rata-rata masa hidup siklon di daerah utara lebih lama dibandingkan di daerah selatan disetiap musim maupun pada keseluruhan (total). Terlihat bahwa rata-rata masa hidup siklon di utara ekuator pada bulan JJA (8,7 hari) adalah yang paling panjang (lama). Sedangkan untuk daerah selatan ekuator paling lama terjadi pada bulan DJF (6,55 hari).

Pada bulan DJF (Desember Januari Februari), siklon di daerah utara ekuator mempunyai ratarata masa hidup yang lebih lama dibandingkan siklon di selatan ekuator. Hal yang sama terjadi pada bulan MAM (Maret April Mei) sama seperti pada bulan DJF. Namun di utara ekuator mengalami kenaikan sedangkan di selatan ekuator mengalami penurunan.

Siklon di daerah utara ekuator mempunyai ratarata masa hidup lebih lama pada bulan JJA (Juni Juli Agustus). Di bulan JJA, daerah selatan ekuator tidak mengalami siklon dalam kurun waktu 2007-2017.

Siklon yang terjadi pada bulan SON (September Oktober November) di utara ekuator mengalami penurunan dari pada bulan JJA. Sedangkan di selatan ekuator pada bulan SON memiliki ratarata masa hidup paling pendek dibandingkan ke tiga musim lainnya.

Berdasarkan penelitian Chan (2000), ENSO dikenal sebagai faktor utama keberagaman aktivitas siklon di Pasifik Barat Laut (dekat wilayah Indonesia). Selain itu, menurut Camargo SJ dan Sobel AH (2005) El Nino mempunyai pengaruh terhadap intensitas, masa hidup serta frekuensi siklon di Pasifik Barat Laut (termasuk wilayah sekitar Indonesia). aOleh karena itu pada penelitian kali ini akan membahas mengenai tiga hal tersebut.

\subsection{Analisis Hubungan El Nino (La Nina) dan Siklon di sekitar wilayah Indonesia}

\subsubsection{Analisis Hubungan El Nino (La Nina) dengan Intensitas Siklon}

Berdasarkan data yang diperoleh dari situs JAXA, dari tahun 2007 sampai 2017 telah terjadi 188 badai siklon di sekitar wilayah
Indonesia atau pada wilayah $90^{\circ} \mathrm{BT}-150^{\circ} \mathrm{BT}$ dan $30^{\circ} \mathrm{LU}-30^{\circ} \mathrm{LS}$. Gambar 4 menunjukan hubungan SSTA (Sea Surface Temperature Anomaly) dalam Nino 3.4 dengan siklon (dalam Skala Saffir-Simpson) di seluruh wilayah penelitian. Untuk melihat hubungannya digunakan scattering plot.

Pada gambar 4, persamaan garis regresinya ialah $y=0,3538 x+2,967$. Nilai regresi $\left(R^{2}\right)$ antara SSTA dengan siklon adalah 0,0455. Nilai regresi ( $R$-Value $)$ tersebut mempunyai arti bahwa hanya sebesar 4,55 \% variasi dari variabel Y (data siklon dalam Skala SaffirSimpson) dapat diterangkan dengan variabel $\mathrm{X}$ (indeks Nino 3.4), sedangkan sisanya yaitu 95,45\% dipengaruhi oleh variabel-variabel yang tidak diketahui.

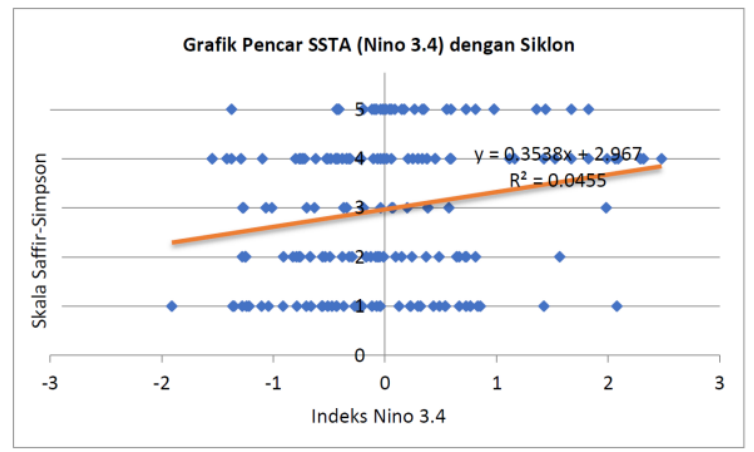

Gambar 4. Grafik pencar SSTA (Nino 3.4) dengan siklon dari tahun 2007-2017

Koefisien korelasi $(R)$ antara SSTA dengan siklon adalah 0,2121. Kedua variabel memiliki hubungan searah dikarenakan koefisien korelasinya positif. Nilai probabilitas ( $P$-Value) untuk gambar 4 ialah 0,0033 . Karena nilai $P$ Value kurang dari 0,05 maka korelasinya signifikan secara statistik. Artinya El Nino (La Nina) memiliki pengaruh terhadap intensitas siklon di sekitar wilayah indonesia.

Dalam data siklon yang telah dikumpulkan terdapat siklon yang terbentuk di daerah utara ekuator dan daerah selatan ekuator. Dalam hal ini diperlukan pemisahan dalam menganalisis supaya dapat terlihat seberapa besar faktor lain yang mempengurahi hubungan variabel $\mathrm{x}$ dengan variabel y di daerah masing-masing. Gambar 5 menjelaskan grafik pencar dari Indeks Nino 3.4 dengan siklon dari tahun 20072017 di sebelah utara ekuator atau pada wilayah $90^{\circ} \mathrm{BT}-150^{\circ} \mathrm{BT}$ dan $0^{\circ} \mathrm{LU}-30^{\circ} \mathrm{LU}$.

Pada gambar 5, persamaan garis regresinya ialah $y=0,3345 x+3,0829$. Nilai regresi $\left(R^{\wedge} 2\right)$ antara SSTA dengan siklon di wilayah utara 
ekuator adalah 0,0372 . Nilai regresi ( $R$-Value) tersebut mempunyai arti bahwa pengaruh variabel x (indeks Nino 3.4) terhadap variabel y (data siklon dalam Skala Saffir-Simpson) adalah sebesar 3,72\%, sedangkan sisanya $96,28 \%$ dipengaruhi oleh faktor lain.

Kedua variabel memiliki hubungan searah dikarenakan koefisien korelasinya positif, yaitu sebesar 0,1929 . Nilai probabilitas ( $P$-Value) untuk gambar 3 ialah 0,0198 . Karena nilai $P$ Value kurang dari 0,05 maka korelasinya signifikan secara statistik. Artinya El Nino (La Nina) memiliki pengaruh terhadap intensitas siklon di sekitar wilayah utara ekuator.

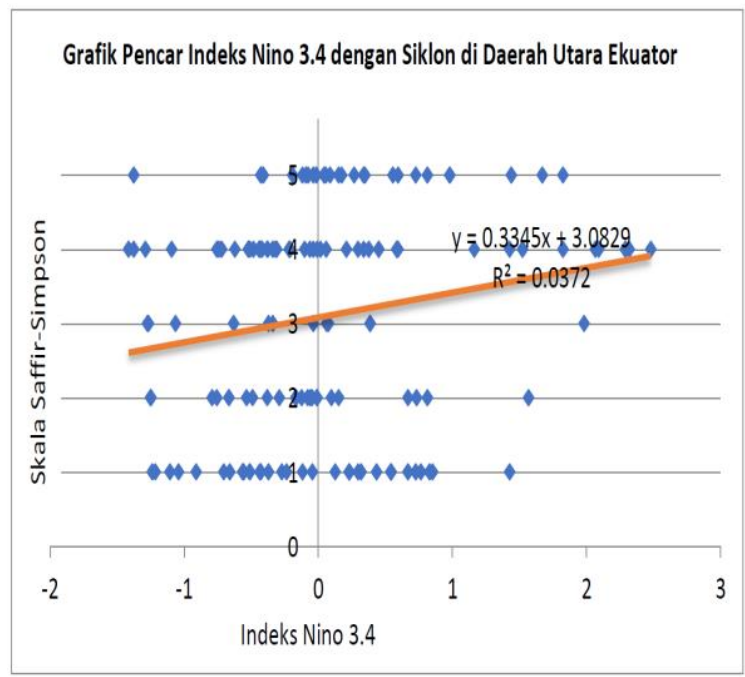

Gambar 5. Grafik pencar SSTA

(Nino 3.4) dengan siklon dari tahun 2007-2017 di utara

ekuator

Selanjutnya, pada gambar 6 menjelaskan grafik pencar dari SSTA (dalam Indeks Nino 3.4) dengan siklon (dalam Skala Saffir-Simpson) dari tahun 2007-2017 di sebelah selatan ekuator atau pada wilayah $90^{\circ} \mathrm{BT}-150^{\circ} \mathrm{BT}$ dan $0^{\circ} \mathrm{LS}-$ $30^{\circ} \mathrm{LS}$.

Untuk daerah wilayah selatan ekuator (gambar 6), persamaan garis regresinya ialah $y=$ $0,3399 x+2,5391$. Nilai regresi $\left(R^{2}\right)$ antara SSTA dengan siklon di wilayah selatan ekuator adalah 0,0636. Nilai regresi ( $R$-Value) tersebut mempunyai arti bahwa hanya sebesar $6,36 \%$ variasi dari variabel Y (data siklon dalam Skala Saffir-Simpson) dapat diterangkan dengan variabel X (indeks Nino 3.4), sedangkan sisanya yaitu $93,64 \%$ dipengaruhi oleh variabel-variabel yang tidak diketahui.
Koefisien korelasi $(R)$ antara SSTA dengan siklon adalah 0,2522. Kedua variabel memiliki hubungan searah dikarenakan koefisien korelasinya positif. Nilai probabilitas ( $P$-Value) untuk gambar 6 ialah 0,1364 . Karena nilai $P$ Value lebih dari 0,05 maka korelasinya tidak signifikan secara statistik. Sehingga El Nino (La Nina) tidak memiliki pengaruh yang signifikan terhadap intensitas siklon di sekitar wilayah selatan ekuator.

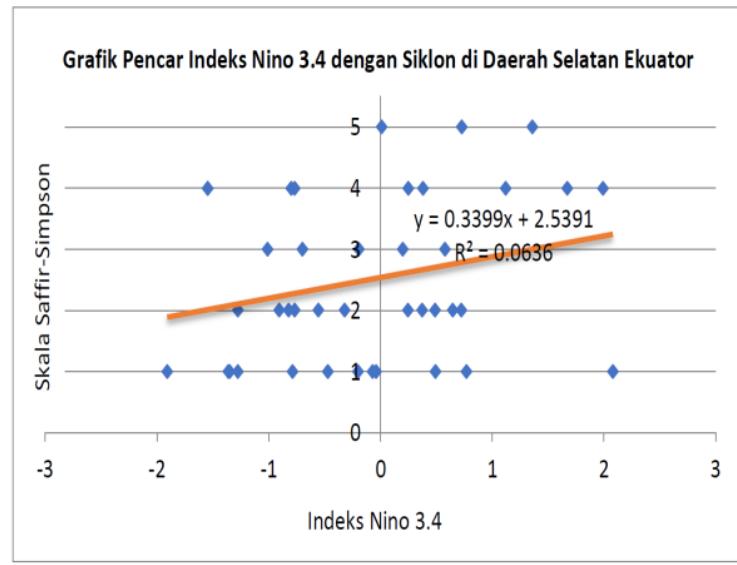

Gambar 6. Grafik pencar SSTA

(Nino 3.4) dengan siklon dari tahun 2007-2017 di selatan ekuator

\subsubsection{Analisis Hubungan El Nino (La Nina) dengan Masa Hidup Siklon}

Dari data siklon yang telah dikumpulkan terdapat variasi masa hidup siklon (dalam satuan hari). Untuk itu diperlukan analisis hubungan El Nino (La Nina) dengan masa hidup siklon. Analisis ini bertujuan untuk melihat pengaruh El Nino (La Nina) terhadap masa hidup siklon. Gambar 7 menunjukan hubungan SSTA (Sea Surface Temperature Anomaly) dalam indeks Nino 3.4 dengan masa hidup siklon (dalam satuan hari) di seluruh wilayah penelitian. Untuk melihat hubungannya digunakan scattering plot.

Pada gambar 7 terlihat persamaan garis regresinya ialah $y=0,7922 x+7,7689$. Nilai regresi $\left(R^{2}\right)$ antara SSTA dengan masa hidup siklon adalah 0,0478 . Nilai regresi ( $R$-Value) tersebut mempunyai arti bahwa pengaruh variabel x (indeks Nino 3.4) terhadap variabel y (data masa hidup siklon dalam hari) adalah sebesar $4,78 \%$, sedangkan sisanya $95,22 \%$ dipengaruhi oleh faktor lain. 
Kedua variabel memiliki hubungan searah dikarenakan koefisien korelasinya positif, yaitu sebesar 0,2186. Nilai probabilitas (P-Value) untuk gambar 5 ialah 0,0026 . Dengan nilai $P$ Value yang kurang dari 0,05 maka korelasinya signifikan secara statistik. Ini artinya, El Nino (La Nina) memiliki pengaruh terhadap masa hidup siklon pada wilayah penelitian.

Hal yang sama dilakukan juga terhadap analisis hubungan El Nino (La Nina) dengan masa hidup siklon, yaitu pemisahan daerah analisis di wilayah utara ekuator dan selatan ekuator. Gambar 8 menjelaskan grafik pencar dari Indeks Nino 3.4 dengan masa hidup siklon dari tahun 2007-2017 di sebelah utara ekuator atau pada wilayah $90^{\circ} \mathrm{BT}-150^{\circ} \mathrm{BT}$ dan $0^{\circ} \mathrm{LU}-30^{\circ} \mathrm{LU}$.

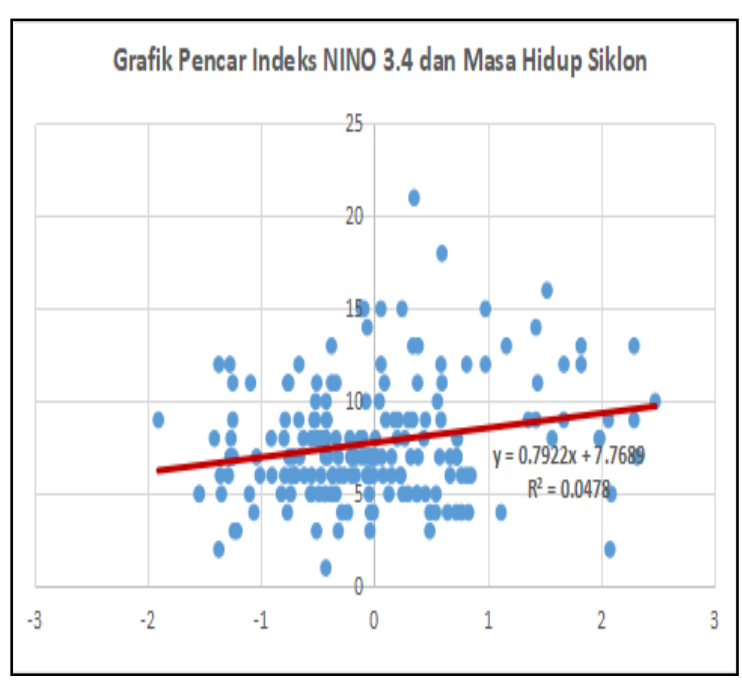

Gambar 7. Grafik pencar SSTA (Nino 3.4) dengan masa hidup siklon dari tahun 2007 2017

Untuk di wilayah utara ekuator, persamaan garis regresinya ialah $y=1,1965 x+8,096$. Nilai regresi $\left(R^{2}\right)$ antara SSTA dengan masa hidup siklon di wilayah utara ekuator adalah 0,0869 . Nilai regresi ( $R$-Value) tersebut mempunyai arti bahwa hanya sebesar 8,69\% variasi dari variabel $\mathrm{Y}$ (data usia hidup siklon) dapat diterangkan dengan variabel $\mathrm{X}$ (indeks Nino 3.4), sedangkan sisanya yaitu $91,31 \%$ dipengaruhi oleh variabel-variabel yang tidak diketahui.
Koefisien korelasi $(R)$ antara SSTA dengan siklon adalah 0,2948. Kedua variabel memiliki hubungan searah dikarenakan koefisien korelasinya positif. Nilai probabilitas ( $P$-Value) untuk gambar 8 ialah 0,000346 . Karena nilai $\mathrm{P}$ Value kurang dari 0,05 maka korelasinya signifikan secara statistik. Ini artinya, El Nino (La Nina) memiliki pengaruh terhadap masa hidup siklon di sekitar wilayah utara ekuator.

Selanjutnya, pada gambar 9 menjelaskan grafik pencar dari SSTA (dalam Indeks Nino 3.4) dengan masa hidup siklon (dalam satuan hari) dari tahun 2007-2017 di sebelah selatan ekuator atau pada wilayah $90^{\circ} \mathrm{BT}-150^{\circ} \mathrm{BT}$ dan $0^{\circ} \mathrm{LS}-$ $30^{\circ} \mathrm{LS}$.

Pada gambar 9 terlihat persamaan garis regresinya ialah $y=-0,2927 x+6,3913$. Nilai regresi $\left(R^{2}\right)$ antara SSTA dengan masa hidup siklon adalah 0,0114 . Nilai regresi $(R$ Value) tersebut mempunyai arti bahwa pengaruh variabel x (indeks Nino 3.4) terhadap variabel y (data masa hidup siklon dalam hari) adalah sebesar $1,14 \%$, sedangkan sisanya 98,86\% dipengaruhi oleh faktor lain.

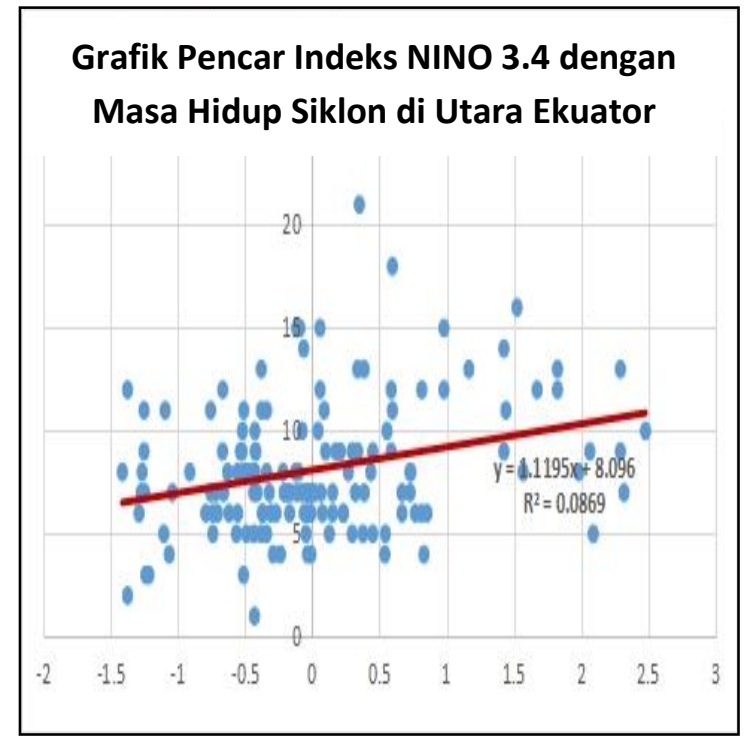

Gambar 8. Grafik pencar SSTA (Nino 3.4) dengan masa hidup siklon dari tahun 2007-2017 di utara ekuator 


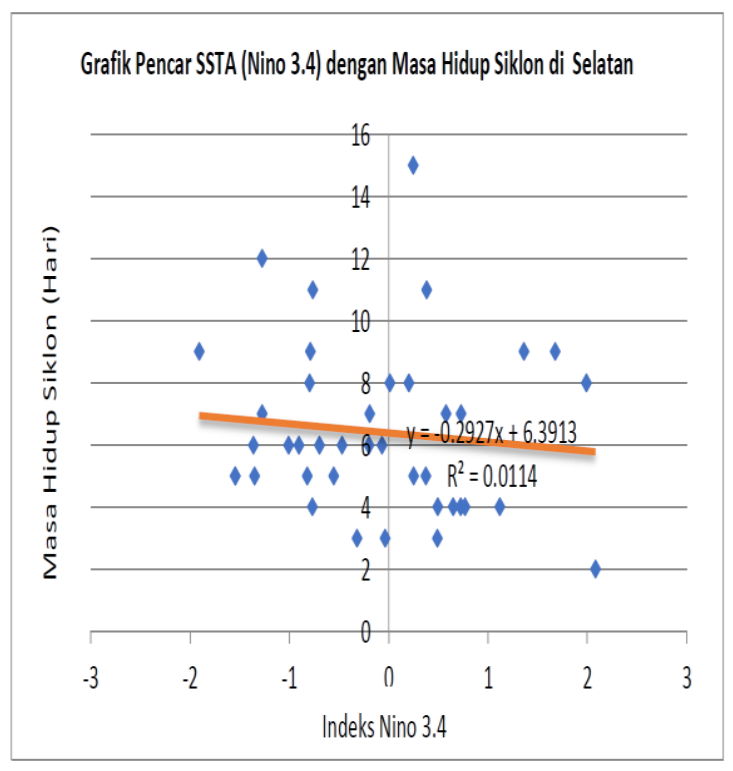

Gambar 9. Grafik pencar SSTA (Nino 3.4) dengan masa hidup siklon dari tahun 2007-2017 di selatan ekuator

Kedua variabel memiliki hubungan yang berbanding terbalik dikarenakan koefisien korelasinya negatif, yaitu sebesar $-0,1068$. Nilai probabilitas ( $P$-Value) untuk gambar 9 ialah 0,5081. Karena nilai $P$-Value lebih dari 0,05 maka korelasinya tidak signifikan secara statistik. Dengan demikian El Nino (La Nina) tidak memiliki pengaruh signifikan terhadap masa hidup siklon di sekitar wilayah selatan ekuator.

\subsubsection{Analisis Hubungan El Nino (La Nina) dengan Frekuensi Siklon}

Berdasarkan hasil pengumpulan data yang diperoleh dari situs JAXA, dari tahun 2007 sampai 2017 telah terjadi 188 badai siklon pada daerah Pasifik Barat Laut atau pada wilayah $90^{\circ} \mathrm{BT}-150^{\circ} \mathrm{BT}$ dan $30^{\circ} \mathrm{LU}-30^{\circ} \mathrm{LS}$. Siklon tersebut muncul pada keadaan anomali suhu permukaan laut (SSTA) yang berbeda-beda. Untuk itu diperlukan analisis frekuensi siklon terhadap berbagai variasi keadaan suhu permukaan laut (dalam hal ini ENSO) di seluruh wilayah penelitian (gambar 10). Analisis ini bertujuan untuk melihat pengaruh El Nino (La Nina) terhadap frekuensi kemunculan siklon. Untuk melihat hubungan kedua variabel tersebut digunakanlah histogram.

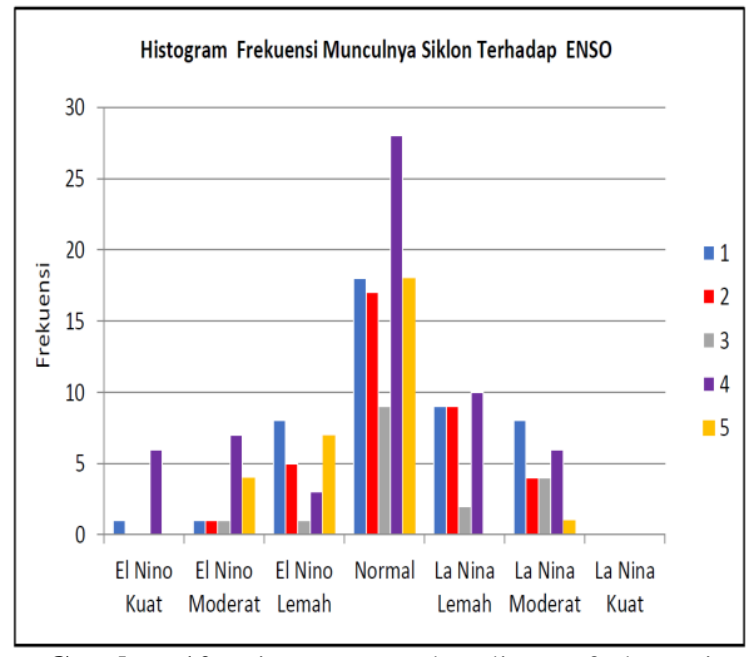

Gambar 10. Histogram perbandingan frekuensi munculnya siklon terhadap ENSO dari 2007-2017

Secara keseluruhan histogram pada gambar 10 menunjukkan hampir semua tipe keadaan pada ENSO memiliki/muncul siklon, kecuali pada saat La Nina Kuat. Keadaan normal mendominasi kemunculan siklon. Siklon yang memiliki skala 1 terjadi pada semua keadaan kecuali La Nina kuat. Frekuensi terbanyak untuk skala 1 terjadi pada saat normal (18 siklon) dan disusul oleh La Nina lemah (9 siklon). Siklon yang memiliki skala 2 terjadi pada semua keadaan kecuali pada El Nino kuat dan La Nina kuat. Frekuensi terbanyak terjadi pada saat normal (17 siklon).

Seperti pada skala 2, siklon dengan skala 3 juga terjadi pada semua keadaan kecuali pada El Nino kuat dan La Nina kuat. Frekuensi terbanyak terjadi pada saat keadaan normal (9 siklon).

Siklon dengan skala 4 terjadi pada semua tipe keadaan pada ENSO kecuali pada saat La Nina kuat. Frekuensi terbanyak tejadi pada saat normal (28 siklon).

Siklon dengan skala 5 terjadi pada saat El Nino moderat, El Nino lemah, normal dan La Nina moderat. Frekuensi terbanyak terjadi pada saat normal (18 siklon).

Gambar 11 menjelaskan histogram perbandingan frekuensi munculnya siklon terhadap ENSO di wilayah utara ekuator. Pada daerah utara ekuator terdapat beberapa perbedaan dalam histogramnya bila 
dibandingkan dengan histogram di gambar 10 .

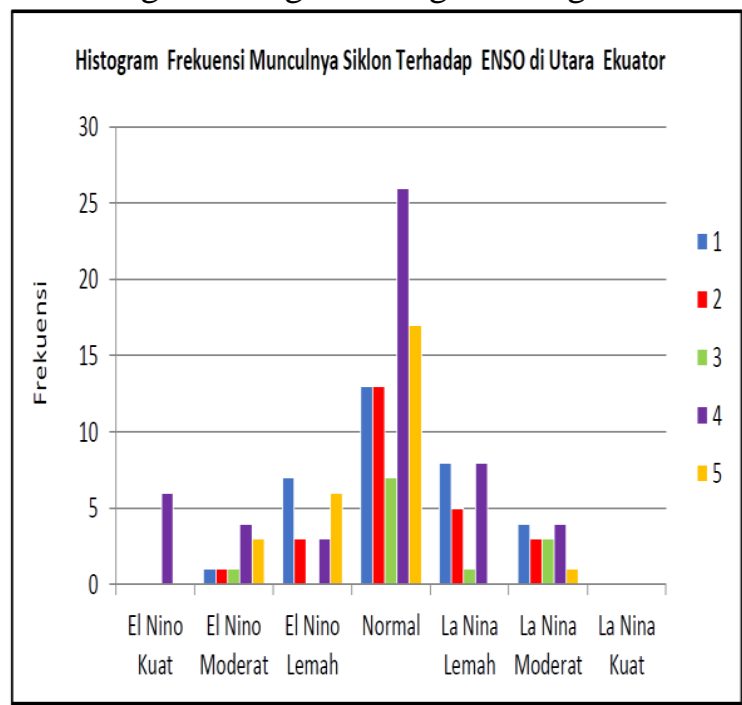

Gambar 11. Histogram perbandingan frekuensi munculnya siklon terhadap ENSO di utara ekuator dari 2007-2017

Secara keseluruhan histogram pada gambar 11, di sebelah utara ekuator kejadian siklon muncul pada semua keadaan kecuali pada saat La Nina kuat. Kemunculan siklon didominasi pada saat keadaan normal. Siklon yang memiliki skala 1 terjadi pada semua keadaan kecuali pada saat El Nino kuat dan La Nina kuat. Frekuensi terbanyak terjadi pada saat normal (13 siklon). Siklon yang memiliki skala 2 memiliki frekuensi pada saat normal (13 siklon).

Siklon dengan skala 3 terjadi pada saat El Nino moderat, normal, La Nina lemah dan La Nina moderat dengan frekuensi terbanyak saat normal (7 siklon). Siklon dengan skala 4 terjadi pada semua keadaan kecuali pada saat La Nina kuat. Frekuensi terbanyak terjadi pada saat normal (26 siklon). Siklon dengan skala 5 terjadi pada saat El Nino moderat, El Nino lemah, normal dan La Nina moderat dengan frekuensi terbanyak terjadi pada saat normal (17 siklon).

Gambar 12 menjelaskan histogram perbandingan frekuensi munculnya siklon terhadap ENSO di wilayah selatan ekuator. Pada daerah selatan ekuator terdapat beberapa perbedaan dalam histogramnya bila dibandingkan dengan histogram di gambar 10 dan 11.

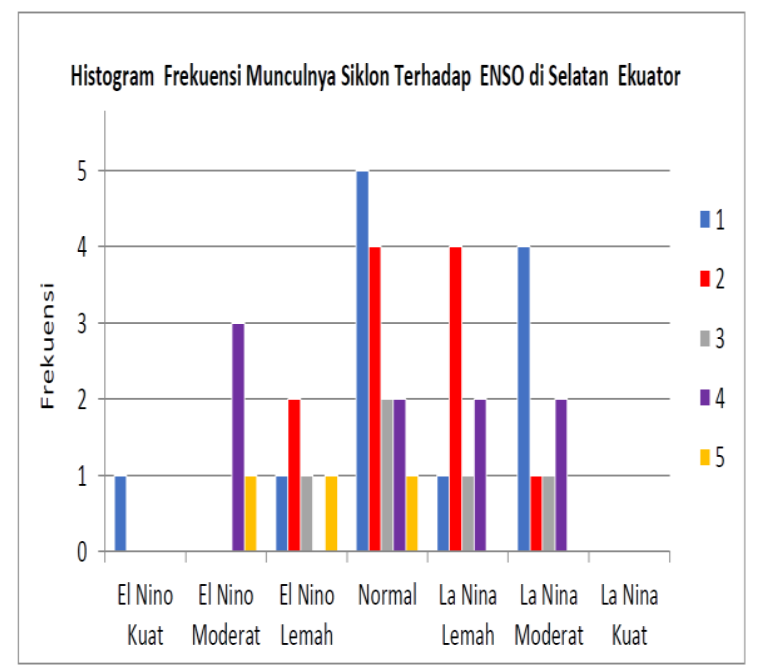

Gambar 12. Histogram perbandingan frekuensi munculnya siklon terhadap ENSO di selatan ekuator dari 2007-2017

Secara keseluruhan histogram pada gambar 12 menunjukkan hampir semua tipe keadaan pada ENSO memiliki/muncul siklon kecuali pada saat La Nina kuat. Siklon skala 1 muncul hampir semua tipe keadaan pada ENSO kecuali pada El Nino moderat dan La Nina kuat. Frekuensi terbanyak terjadi pada saat normal (5 siklon) di susul oleh La Nina moderat (4 siklon). Siklon dengan skala 2 terjadi pada saat El Nino lemah, normal, La Nina lemah dan La Nina moderat. Frekuensi terbanyak muncul pada saat La Nina lemah (4 siklon) dan normal (4 siklon).

Siklon dengan skala 3 terjadi pada saat El Nino lemah, normal, La Nina lemah dan La Nina moderat dengan frekuensi terbanyak terjadi pada saat normal (2 siklon). Siklon dengan skala 4 terjadi pada saat El Nino moderat, normal, La Nina lemah dan La Nina moderat dengan frekuensi terbanyak terjadi pada saat El Nino moderat (3 siklon). Siklon dengan skala 5 terjadi pada saat El Nino lemah, El Nino moderat dan normal masing-masing satu siklon.

\subsection{Pembahasan}

Dari hasil penelitian didapatkan beberapa poin penting. Tabel 2 menjelaskan hasil penelitian dalam hal hubungan El Nino (La Nina) dengan intensitas dan masa hidup siklon, baik secara keseluruhan wilayah penelitian $\left(90^{\circ} \mathrm{BT}-150^{\circ} \mathrm{BT}\right.$ dan $30^{\circ} \mathrm{LU}-30^{\circ} \mathrm{LS}$ ), di sebelah utara ekuator maupun di sebelah selatan ekuator. 
Secara statistik, El Nino (La Nina) memiliki pengaruh terhadap intensitas dan masa hidup siklon di sekitar wilayah Indonesia. Pada daerah sebelah utara ekuator pun El Nino (La Nina) signifikan berpengaruh terhadap intensitas dan masa hidup siklon.

Pada bagian selatan ekuator, secara statistik El Nino (La Nina) tidak memiliki pengaruh terhadap intensitas dan masa hidup siklon. Hal ini kemungkinan dikarenakan hanya sedikit siklon yang terjadi di selatan ekuator dari tahun 2007-2017 dibandingkan dengan daerah utara ekuator. Apabila kurun waktu pengambilan data siklon di tambah, bukan tidak mungkin di selatan ekuator mendapat hasil yang berbeda mengingat bertambahnya kejadian siklon di selatan ekuator.

Untuk analisa frekuensi, pada hasil penjelasan histogram dapat dituangkan dalam tabel 3 dibawah ini.

Pada kenyataannya semua siklon bisa terjadi pada saat keadaan normal, bahkan frekuensi terbanyak pada semua skala ada pada saat keadaan normal. Untuk analisis frekuensi siklon ini belum terlihat pengaruhnya baik pada saat El Nino maupun La Nina dan memerlukan penelitian lebih lanjut mengenai hal ini

Tabel 2. Hasil penelitian pada analisis intensitas dan masa hidup siklon

\begin{tabular}{|c|c|c|c|c|c|}
\hline Analisis & $\begin{array}{c}\text { Wilaya } \\
\mathbf{h}\end{array}$ & $\begin{array}{c}\text { Nilai } \\
\text { Regresi } \\
\left(\boldsymbol{R}^{\mathbf{2}}\right)\end{array}$ & $\begin{array}{c}\text { Koefisien } \\
\text { Korelasi }(\boldsymbol{R})\end{array}$ & P-Value & Ket. \\
\hline \multirow{3}{*}{$\begin{array}{c}\text { Intensitas } \\
\text { Siklon }\end{array}$} & Total & 0,0455 & 0,2121 & 0,0033 & Signifikan \\
\cline { 2 - 6 } & Utara & 0,0372 & 0,1929 & 0,0198 & Signifikan \\
\cline { 2 - 6 } & Selatan & 0,0636 & 0,2522 & 0,1364 & $\begin{array}{c}\text { Tidak } \\
\text { Signifikan }\end{array}$ \\
\hline \multirow{2}{*}{$\begin{array}{c}\text { Masa } \\
\text { Hidup } \\
\text { Siklon }\end{array}$} & Total & 0,0478 & 0,2186 & 0,0026 & Signifikan \\
\cline { 2 - 6 } & Utara & 0,0869 & 0,2948 & 0,000346 & Signifikan \\
\cline { 2 - 6 } & Selatan & 0,0114 & $-0,1068$ & 0,5081 & $\begin{array}{c}\text { Tidak } \\
\text { Signifikan }\end{array}$ \\
\hline
\end{tabular}

Tabel 3. Hasil penelitian pada analisis frekuensi siklon

\begin{tabular}{|c|c|c|c|c|c|c|c|c|c|c|c|}
\hline \multirow{2}{*}{\multicolumn{2}{|c|}{ Keadaan }} & \multicolumn{10}{|c|}{ Skala Saffir-Simpson } \\
\hline & & \multicolumn{2}{|c|}{1} & \multicolumn{2}{|c|}{2} & \multicolumn{2}{|c|}{3} & \multicolumn{2}{|c|}{4} & \multicolumn{2}{|r|}{5} \\
\hline \multirow{3}{*}{ El Nino } & Kuat & \multirow{3}{*}{10} & 1 & \multirow{3}{*}{6} & 0 & \multirow{3}{*}{2} & 0 & \multirow{3}{*}{16} & 6 & \multirow{3}{*}{11} & 0 \\
\hline & Moderat & & 1 & & 1 & & 1 & & 7 & & 4 \\
\hline & Lemah & & 8 & & 5 & & 1 & & 3 & & 7 \\
\hline \multicolumn{2}{|c|}{ Normal } & \multicolumn{2}{|c|}{18} & \multicolumn{2}{|c|}{17} & \multicolumn{2}{|c|}{9} & \multicolumn{2}{|c|}{28} & \multicolumn{2}{|c|}{18} \\
\hline \multirow{3}{*}{$\begin{array}{c}\mathrm{La} \\
\text { Nina }\end{array}$} & Lemah & \multirow{3}{*}{17} & 9 & \multirow{3}{*}{13} & 9 & \multirow{3}{*}{6} & 2 & \multirow{3}{*}{16} & 10 & \multirow{3}{*}{1} & 0 \\
\hline & Moderat & & 8 & & 4 & & 4 & & 6 & & 1 \\
\hline & Kuat & & 0 & & 0 & & 0 & & 0 & & 0 \\
\hline
\end{tabular}

\section{KESIMPULAN}

Sejak awal tahun 2007 sampai akhir tahun 2017 telah terjadi 188 badai yang masuk kategori badai siklon (dalam skala saffir-simpson). Dalam penelitian ini dianalisa mengenai intesitas, frekuensi, dan masa hidup siklon terhadap ENSO baik di seluruh cakupan wilayah penelitian $\left(90^{\circ} \mathrm{BT}-150^{\circ} \mathrm{BT}\right.$ dan $30^{\circ} \mathrm{LU}-$ $\left.30^{\circ} \mathrm{LS}\right)$, di sebelah utara ekuator $\left(90^{\circ} \mathrm{BT}\right.$ $150^{\circ} \mathrm{BT}$ dan $\left.0^{\circ} \mathrm{LU}-30^{\circ} \mathrm{LU}\right)$, maupun di sebelah selatan ekuator $\left(90^{\circ} \mathrm{BT}-150^{\circ} \mathrm{BT}\right.$ dan $0^{\circ} \mathrm{LS}$ $\left.30^{\circ} \mathrm{LS}\right)$. 
Kesimpulan yang didapat dari penelitian ini adalah bahwa El Nino (La Nina) memiliki pengaruh positif yang signifikan terhadap intensitas dan masa hidup siklon di sekitar wilayah Indonesia dengan nilai korelasi sebesar 0,2121 untuk intensitas siklon dan 0,2186 untuk masa hidup siklon. Begitu pula untuk daerah utara ekuator di sekitar wilayah Indonesia, El Nino (La Nina) memiliki pengaruh positif yang signifikan terhadap intensitas dan masa hidup siklon dengan nilai korelasi sebesar 0,1929 untuk intensitas siklon dan 0,2948 untuk masa hidup siklon.

Pada bagian selatan ekuator tidak terdapat pengaruh yang signifikan baik pada intesitas maupun pada masa hidup siklon. Hal ini dikarenakan tidak terlalu banyak siklon yang terjadi pada daerah ini pada kurun waktu 20072017 sehingga tidak bisa memperlihatkan hasil yang maksimal pada penelitian ini. Apabila kurun waktu pengambilan data siklon ditambah, bukan tidak mungkin pada daerah ini akan memperlihatkan hasil yang berbeda seiring dengan banyaknya data siklon yang diperoleh.

Pengaruh El Nino (La Nina) terhadap frekuensi siklon belum dapat terlihat dengan jelas pada penelitian ini sehingga diperlukan penelitian lebih lanjut mengenai hal ini.

\section{UCAPAN TERIMA KASIH}

Penulis secara khusus mengucapkan terima kasih yang sebesar-besarnya kepada semua pihak yang telah membantu. Penulis banyak menerima bimbingan, petunjuk dan bantuan serta dorongan dari berbagai pihak baik yang bersifat moral maupun material. Pada kesempatan ini penulis menyampaikan rasa terima kasih yang sebesar-besarnya kepada Sekolah Tinggi Meteorologi Klimatologi dan Geofisika serta panitia yang telah memberikan kesempatan kepada penulis. Akhir kata, penulis mengucapkan terimakasih kepada Akmal Firmansyah, Atang Purnama dan Sinta Dewi Purnama atas bantuan teknis dan sarannya.

\section{DAFTAR PUSTAKA}

Done, T. J. 1992. Effect of Tropical Cyclone Waves on Ecological and Geomorphological Structures on The Great Barrier Reef. Queensland : Elsevier.
Ribuan Warga Taiwan Mengunsi Akibat Topan Nepartak,(http://internasional.republika.co. $\mathrm{id} /$ berita/internasional/global/16/07/08/o9zj f0366-ribuan-warga-taiwan-mengungsiakibat-topan-nepartak), diakses pada 1 Maret 2018.

Haryani, N. S., dan Zubaidah, A. 2012. Dinamika Siklon Tropis di Asia Tenggara menggunakan Data Penginderaan Jauh. $324: 54-58$.

Kepert. 2010. Tropical Cyclone Structure and Dynamics. Global prespective on tropical cyclones, 3-51.

Saha, K. 2010. Tropical Circulation Systems and Monsoons. Springer-Verlag Berlin Heidelberg.

Bayong, T. H. K. 2004. Klimatologi. Bandung : Penerbit ITB.

Horstmeyer, S. L. 2011. Tropical Cyclones, in The Weather Almanac: A Reference Guide to Weather, Climate, and Related Issues in the United States and its Key Cities. Twelfth Edition. Hoboken, New Jersey, USA : John Wiley \& Sons, Inc.

Terry, J. P. 2007. Tropical Cyclone : Climatology and Impacts in The South Pacific. The University of The South Pacific, Suva : Springer.

Allan, R. J. 2000. ENSO and climatic variability in the past 150 years. El Niño and the southern oscillation: multiscale variability and global and regional impacts. New York: Cambridge University Press. 3-55.

Gilantz, M. H. 2001 Currents of Change : El Nino's Impact on Climate and Society. New York: Cambridge University Press.

Lander M.A. 1994. An exploratory analysis of the relationship between tropical storm formation in the western North Pacific and ENSO. Mon Weather Rev 122:636-651.

Chan, J. C. L. 1985. Tropical cyclone activity in the northwest Pacific in relation to the $\mathrm{El}$ Niño/Southern Oscillation phenomenon. Mon. Wea. Rev. 113. 599-606.

Wu, G., dan Lau N. C. 1992. A GCM Simulation of The Relationship Between Tropical-Storm Formation And ENSO. Mon. Wea. Rev., 120 , 958-977. 
Camargo S. J. dan Sobel A. H. 2005. Western North Pacific Tropical Cyclone Intensity And ENSO. J Clim. 18:2996-3006.

Chan J. C. L. 2000. Tropical cyclone activity over the western North Pacific associated with El Niño and La Niña events. J Clim 13:2960-2972.
JAXA / EORC Tropical Cyclone Database. (http://sharaku.eorc.jaxa.jp/TYP_DB/index _e.shtml diakses pada 26 Februari 2018).

Data Indeks El Nino (Nino 3.4). (https://www.bmkg.go.id/iklim/informasiindex-elnino.bmkg diakses pada 26 Februari 2018).

Levin, R. I., dan Rubin, D. S. 2008. Statistic for Management. 7th Edition. Pearson. 